\title{
Tension over equitable allocation of water: estimating renewable groundwater resources beneath the West Bank and Israel
}

\author{
M. M. Mansour ${ }^{1}$, D. W. Peach ${ }^{1}$, A. G. Hughes ${ }^{1}$ \& N. S. Robins ${ }^{2 *}$ \\ ${ }^{1}$ British Geological Survey, Kingsley Dunham Centre, Keyworth, Nottingham, \\ NG12 5GG, UK \\ ${ }^{2}$ British Geological Survey, Maclean Building, Wallingford, Oxfordshire OX10 8BB, \\ UK \\ *Corresponding author nsro@bgs.ac.uk \\ Word count 4600 \\ Running header: Groundwater in Israel and the West Bank
}

\begin{abstract}
Competition for water resources between Palestine and Israel is an ongoing cause of tension. The Western Aquifer Basin forms a major part of the complex, largely karst, limestone system of the West Bank Mountain Aquifer. The aquifer crops out and is recharged solely in the semi-arid uplands of the West Bank and groundwater flows west beneath Israel to discharge at the Yarqon and Nahal Taninim springs near the Mediterranean coast. Annual recharge to the aquifer is not easy to quantify but lies within the range $270 \times 10^{6}$ to $455 \times 10^{6} \mathrm{~m}^{3} \mathrm{a}^{-1}$, and current uncertainties do not support definition of a single value of long-term average recharge. The resource is heavily exploited and abstraction is directly controlled and apportioned between Israel and the West Bank by Israel. The key to equitable apportionment is the determination of the long-term average recharge to the basin, which also requires definition of the eastern boundary of the basin to confirm the recharge area. Calculations include empirical formulae and process based models which are likely to constrain the best estimate provided that there is appropriate, on-going monitoring. The improved understanding can then be fed back into the model.
\end{abstract}

The Western Aquifer Basin of the West Bank Mountain Aquifer provides both Israel and the occupied territory of Palestine with a significant water resource. Although the aquifer crops out and is recharged only in Palestine, it dips beneath the Armistice Line and forms a confined aquifer beneath central Israel, ultimately discharging to large springs close to the Mediterranean Sea. Apportionment of the resource is currently managed by Israel. However, the Palestinian Authority believes the apportionment to be biased towards Israel (World Bank 2009) and is keen to demonstrate a scientific basis for dividing the resource between the two stakeholders.

The key to equitable apportionment of the resource is an agreed annual recharge estimate for the aquifer system and a method of converting successive annual values into a long term average volume. There are two issues for resolution: the first is the definition of the eastern boundary of the aquifer basin, i.e. defining the recharge area, 
and the second is the identification of the recharge processes in order to support the calculation of annual recharge volumes. Both issues need to be resolved using defensible scientific arguments so that calculated values of annual recharge are acceptable to the broader scientific community. Further, both issues need to be defined in a logical and robust manner and presented in a language that can be appreciated by politicians and other non-technical decision makers.

The intractability of the problems surrounding the determination of annual recharge are reflected in the current range of values reported in the scientific literature. These values lie within the range $270 \times 10^{6}$ to $455 \times 10^{6} \mathrm{~m}^{3} \mathrm{a}^{-1}$ (Hughes et al. 2008). Early recharge estimates were based on simple empirical relationships which neither acknowledge the complexity of the partly karstic, fractured aquifer, nor the extreme annual variability of a semi-arid climate. The range of results has not helped the process of negotiation and agreement of allocation. Average values have been adopted, as for example, those quoted in the various Oslo Agreements, but neither stakeholder is happy with the current science knowledge base (World Bank 2009).

There is a philosophical and cultural issue in the region over water and who owns it. Theoretically there is enough water available to sustain the population in Israel and the Palestinian territories (Deconinck 2006). However, Israeli philosophy identifies an 'ideological importance' for irrigated agriculture as part of its 'make the desert bloom' adage. While $60 \%$ of the regional water resource is committed to agricultural activity by Israel, the investment yields only $1.6 \%$ of that nation's GDP. Stakeholder agreement on apportionment of the resource is further exacerbated by Israel's insistence that it keeps control of the water resources under any future peace agreement (Deconinck 2006). The economy of Palestine is, therefore, partly currently constrained by the Israeli agricultural sector which is relatively buoyant (Rogers 2004).

A World Bank Sector Report (World Bank 2009) states that Palestine is now completely dependent on Israel for access to all its scarce resources. This has led to 'systematic and severe constraints on Palestinian development of water resources' despite the joint governance rules and water allocations established under the 1995 Oslo interim peace agreement. The World Bank report, however, also lays part of the blame on the Palestinian Authority which is described as 'struggling to establish even a basic water infrastructure and management'.

A key to stimulating the Palestinian economy in the future will be the availability of water for agriculture and industry while ensuring that the limited water resource that is available is used to the best advantage of the economy. Once the political and economic constraints on developing the Palestinian economy are allowed to ease then demand for water is likely to increase in order to satisfy economic targets. The dispute over the resource available in the Western Aquifer Basin is then likely to intensify towards a point of conflict. It is essential, therefore, that the apportionment based on reliable calculation of annual recharge, i.e. the renewable resource, is resolved as soon as practicable, so that the politicians of tomorrow can be armed with appropriate and defensible scientific analysis.

A first step to inform the politicians, on both sides of the Armistice Line, was the publication of the Hydrogeological Map of the West Bank (PWA 2004). This was 
prepared to the UNESCO standard legend (UNESCO 1983) at 1: 250000 scale by the British Geological Survey working alongside the Palestinian Water Authority. A series of inset diagrams and information boxes describe the various aquifer systems in non-technical language. The map provides a synopsis of the basic understanding of the Palestinian aquifer systems and demonstrates that the systems are complex and difficult to analyse given a data-scarce environment.

This paper describes the complexity of the Western Aquifer Basin and the difficulties in deriving a scientifically robust and defensible long-term average (LTA) recharge value on which to base any apportionment of the resource. It emphasises the importance of the determinations which, in due course, will be vital to the avoidance of potential conflict over the use of available, but finite, renewable groundwater resources.

\section{The Western Aquifer Basin}

The anticlinal axis of the Mountain Aquifer system straddles the West Bank (PWA 2004). It creates an upland area comprising limestones with subordinate argillaceous rocks, with the Eastern Aquifer Basin draining towards the Jordan valley and the Western Aquifer Basin towards Israel and the Mediterranean Sea. There is also a smaller Eocene sedimentary basin called the North-Eastern Basin (Fig. 1). Direct rainfall recharge in the wetter areas percolates to the water table in the limestones where it is transported down hydraulic gradient via secondary permeability and karstic flow. Perched groundwater emerges locally from springs and is routed via ephemeral wadi flows and sinks where it contributes indirectly to recharge.

\section{$<$ Fig 1 about here $>$}

The limestone aquifer comprises two hydraulically distinct zones, the Upper Aquifer and Lower Aquifer (Fig. 2). They are separated by the weakly permeable Yatta Formation and are distributed within an anticline with a broadly north south axis (Rofe \& Raffety 1965; PWA 2004). The piezometry and geological structure indicate a defined groundwater divide between the Western Aquifer and the Eastern Aquifer basins (Fig. 2). The divide runs parallel to the topographical surface water divide although there is a considerable offset of the groundwater divide to the west towards the crest of the anticline. Rofe \& Raffety (1965) identified the axis of the main anticline as a dominant influence on groundwater flow directions. However, they assumed that groundwater flowpaths are primarily controlled by the dip of the more permeable strata, but potentiometric levels indicate that the groundwater divide may not always be coincident with the structural divide. In many places the groundwater divide is also close to the topographic divide, and in other areas, the exact location of the divide appears to be influenced by local patterns of groundwater exploitation.

\section{$<$ Fig.2 about here $>$}

In general, the topographic divide is to the east of the structural divide, and hence an assumption that the divide is always coincident with the structural divide will lead to an underestimate of the recharge area of the Western Aquifer Basin and an overestimate of the recharge area of the Eastern Aquifer basin. The boundaries of the 
North Eastern Basin, as mapped by Rofe and Raffety, contrast with surface water flow directions, and are difficult to justify. These uncertainties need resolution before any sensible apportionment of the resources available within the Western Aquifer Basin can be attempted.

\section{Recharge and empirical renewable resource estimates}

LTA annual rainfall ranges from less than $100 \mathrm{~mm}$ over the Dead Sea to over $300 \mathrm{~mm}$ in the south west, and $400 \mathrm{~mm}$ over the north west of the West Bank. Rainfall is greatest over much of the central groundwater divide, between the Western and Eastern Aquifer basins, where it is nearly $600 \mathrm{~mm}$. Annual potential evaporation ranges from about $2500 \mathrm{~mm}$ over the Dead Sea and much of the Jordan valley to over $1850 \mathrm{~mm}$ in the north western part of the West Bank. Recharge to the Western Aquifer Basin, calculated over a significant number of rainfall cycles or years, defines the long term renewable groundwater potential. However, given that potential evapotranspiration almost always exceeds rainfall in any given year, the concept of LTA rainfall/recharge is barely applicable (Flint et al. 2002; Lewis \& Walker 2002; Wood et al. 1997). The length and intensity of rainfall events, or groups of events, heavily influence recharge occurrence. Focus also needs to be made on detailed recharge routes such as rainwater collecting in depressions and streams, and rapid infiltration via fractures or solution channels. Actual recharge is susceptible to nearsurface conditions. It is greatest where vegetation is sparse, soils are thin and permeable and least through thick alluvial soils, which have a high retention storage for wet season rains and which serve to enhance evapotranspiration (de Vries \& Simmers 2002).

The recharge mechanisms cannot be defined by any one analytical system, for example the commonly applied soil moisture deficit (SMD) analysis developed by Penman (1948) for application in humid environments. The complex geological setting of the aquifer and the paucity of data describing the physical properties of the karst limestone aquifer rule out numerical groundwater modeling as a means of deriving a defensible LTA annual recharge value. To date, groundwater flow models of the aquifer have largely concentrated on simulating potentiometric surfaces for steady state conditions.

Given these difficulties, a number of empirical relationships between recharge and rainfall have been developed for the region. Goldschmidt (1955) used a simple water balance method and assumed that a seemingly modest $360 \mathrm{~mm}$ of the average annual rainfall is required to overcome evaporative losses, and equated LTA recharge to the aquifer as $90 \%$ of the LTA rainfall minus $360 \mathrm{~mm}$. Allowing $4 \%$ further loss to storm runoff a value of $317 \times 10^{6} \mathrm{~m}^{3} \mathrm{a}^{-1}$ was obtained for the aquifer outcrop (excluding aquiclude outcrop and using an arbitrary aquifer boundary to the east). Goldschmidt \& Jacobs (1958) argued that almost the entire discharge from the aquifer was accounted for in the Yarqon and Nahal Taninim springs situated near Haifa on the Mediterranean coast and equated the combined yield from the two springs plus known abstraction to the total recharge available to the aquifer. This approach provided a value for recharge of $326 \times 10^{6} \mathrm{~m}^{3} \mathrm{a}^{-1}$ for an average year. Estimates were revised after increasing abstraction began to derogate spring discharge and better estimates of abstraction became available. Assaf et al. (1993) estimated a safe yield for the Western Aquifer Basin of $350 \times 10^{6} \mathrm{~m}^{3} \mathrm{a}^{-1}$ of which $40 \times 10^{6} \mathrm{~m}^{3} \mathrm{a}^{-1}$ flowed from the 
Taninim spring. This was revisited by Bachmat (1995) and again by (MNIWC 1999) yielding a revised safe yield estimate of $399 \times 10^{6} \mathrm{~m}^{3} \mathrm{a}^{-1}$.

A consistent set of recharge estimates were derived for the Western Aquifer Basin of around $350 \times 10^{6} \mathrm{~m}^{3} \mathrm{a}^{-1}$ (Table 1), a value since reaffirmed by SUSMAQ (2003). Although these estimates are consistent within a given range, only the work by Goldschmidt \& Jacobs (1958) and Assaf et al. (1993) provide best estimates of recharge by equating calculated discharge and abstraction to recharge. However, although these estimates are based on discharge used as a surrogate for recharge, they include uncertainties of the precise volume of water abstracted from the aquifer over a given period, do not account for changes in storage or of the possibility of unidentified losses.

\section{Likely recharge processes}

Various workers have asserted that up to half the LTA rainfall is likely to arrive at the water table as recharge even in a semi-arid environment (Hoetzl 1995; Leduc et al. 1997; de Vries \& Simmers 2002). Recharge processes include both primary recharge or direct rainfall recharge, and secondary mechanisms such as overland and stream flow losses through infiltration and by pass flow via fractures and sink holes (Lerner et al. 1990; Simmers et al. 1997). Bredenkamp et al. (1995) observed that cumulative rainfall departures from average rainfall conditions provide useful indicators of the range of hydrological responses that may occur in semi-arid regions. Vegetation promotes capillary rise and vapour transport of groundwater towards the root zone causing an upward flux towards the ground surface (De Vries \& Simmers 2002). Any change in vegetation through agricultural development, in addition to recharge returns from irrigation, may significantly impact recharge.

Topographical depressions are also an important part of the recharge mechanism in semi-arid areas (Scanlon et al. 1997; Leduc et al. 1997). Recharge begins to occur beneath water filled depressions once a wetting threshold (WT) has been exceeded, for example, Herczeg et al. (1997) found that dolines in Australian karst limestone became active recharge centres after sustained rain of $>2.5 \mathrm{~mm} \mathrm{~d}^{-1}$ had been maintained for three days. The WT idea has been developed further by Lange et al. (2003) who show that the steep and rocky slopes in the West Bank and Israeli mountains generate surface overland flow rather than direct recharge into the underlying karst aquifer even during prolonged and intense rainfall events. Experimentation carried out by Lange et al. (2003) has demonstrated that WT values can be derived for specific topographical conditions, above which both runoff and infiltration start to occur.

Recharge to areas such as the Western Aquifer Basin depends on discrete processes peculiar to semi-arid upland karst areas (Scanlon et al. 1997). Under humid conditions, with vegetation and soil covering the aquifer, the SMD approach championed by Penman (1948) can best be applied. However, under drier conditions experimental work in the region by Lange et al. (2003) suggests that a WT approach would be more appropriate because soil moisture field capacity is rarely achieved in this type of environment. Additionally, rainfall events tend to be short and intense promoting runoff despite the soil not being at field capacity. 
Lange et al. (2003) investigated the potential recharge in a semi-arid catchment in the central part of the exposed Western Aquifer Basin. It was found that runoff was only generated from previously dry soil when a specific rainfall threshold was reached, after which the runoff slowly increased to a maximum $85 \%$ of the rainfall intensity. The rate of wetting up is defined by the soil threshold, which is the maximum amount of water absorbed by the soil before any runoff is generated. The more traditional SMD approach (Penman 1948) can still be applied in the more humid areas, and the respective models can be brought together using an innovative distributed recharge model approach which also allows various secondary recharge processes to be switched in and out as required (Hughes et al. 2006).

\section{Recharge models}

Rofe and Raffety (1965) used the Penman (1948) SMD approach to calculate recharge to the West Bank aquifers. This work was unique in the early studies in the region as it was the only estimate of recharge that was founded on the application of a process approach, all the other attempts (Table 1) being empirical.

\section{$<$ Table 1 about here>}

A regional scale distributed recharge model has also been developed for the West Bank Mountain Aquifer system (Hughes et al. 2008). This demonstrates both the current understanding of the recharge processes over the unconfined part of the aquifer and current modelling capability. It provides recharge outputs that are compatible with those derived both from existing empirical recharge estimates and output from regional scale groundwater flow models for the system. The model provides a viable platform for the assessment of distributed recharge to the unconfined part of the Western Aquifer Basin using the ZOODRM code (Mansour \& Hughes 2004) and was used on a catchment basis before it was deployed across the whole of the West Bank (Hughes et al. 2008). This contributes significantly to the on-going debate over apportionment by refining the overall recharge estimate to the Western Aquifer Basin.

Hughes et al. (2008) describe the functioning of the model and how it deals with surface routing, spring discharges as well as urban and irrigated land. Various runs were carried out based on the WT method using a range of likely values and the SMD method using root constant and wilt point values distributed according to land use. Various simulations were undertaken. Three examined the impact of varying the WT; $\mathrm{WT}=20,30$ and $40 \mathrm{~mm}$, together with a single SMD run. For the WT (WT = $30 \mathrm{~mm}$ ) and the SMD run, two additional runs were undertaken with urban recharge processes and losses from irrigated fields activated and one run was undertaken to examine the impacts of smoothing the potential evaporation data. An additional composite run was prepared using a distributed mixture of SMD and WT methods.

The boundary between the applicability of the SMD and WT methods is the $500 \mathrm{~mm}$ LTA rainfall contour (Lerner et al. 1990), although $<10 \%$ of the Western Aquifer Basin, i.e. the upper part of the limestone outcrop towards the topographical divide particularly in the northern sector, receives greater than $500 \mathrm{~mm} \mathrm{a}^{-1}$ rainfall at 
outcrop. Comparison of the model output with measured surface water flows has been undertaken to provide validation of the recharge model. Wadi gauging stations close to the boundary of the outcrop area of the Western Aquifer Basin were selected, and the modelled results show reasonable agreement with the measured flows (Hughes et al. 2008). The modelled values for recharge (Table 2) widen the range derived by earlier workers (Table 1). As would be expected the WT values are consistently higher than those derived from the SMD method while the composite WT/SMD run yields a value of LTA recharge of approximately $310 \times 10^{6} \mathrm{~m}^{3} \mathrm{a}^{-1}$.

\section{$<$ Table 2 about here>}

\section{Discussion}

Estimates of recharge to the Western Aquifer Basin have been generated using a variety of empirical and process based methodologies. A range of estimates is emerging (Tables 1 and 2), and no single value or constrained range of values for LTA recharge can be considered as the best available estimate. Selection of a single value to report to the administrators responsible for apportioning the renewable resource between Palestine and Israel remains unwise, as it is not yet possible to deliver a number that is justifiable and defensible. In addition, agreement must be reached on the location of the eastern groundwater divide to establish the active recharge area.

The empirical calculations achieved the objective of constraining the value, but within a broad range. Values have also been obtained by SMD analysis (Rofe \& Rafferty 1965) and a combination of SMD and WT calculations (Hughes et al. 2008). Both suffer from lack of supporting input data.

The modelling work (Hughes et al. 2008) starts to constrain the range of recent values for LTA recharge to the Western Aquifer Basin. The likely most realistic estimate from the work by Hughes et al. is the combined WT/SMD model which indicates LTA annual recharge to be around $310 \times 10^{6} \mathrm{~m}^{3} \mathrm{a}^{-1}$. This is lower than earlier estimates which range up to $366 \times 10^{6} \mathrm{~m}^{3} \mathrm{a}^{-1}$ with a mean value of $350 \times 10^{6} \mathrm{~m}^{3} \mathrm{a}^{-1}$ for the Western Aquifer Basin (Table 1). It is important that further work is carried out to increase confidence in this perceived 'best' value.

The pathway towards obtaining a defensible LTA recharge value for the Western Aquifer Basin lies in data gathering. Accurate meteorological data coupled with spring flow and wadi flow time series data, including values of seasonal floods, are essential to support future recharge process modelling work. Effort is ongoing to acquire these data but lack of co-ordination and direction (World Bank 2009) means that not all the data that are needed are currently being gathered.

\section{Conclusions}

The complex geological structure, combined with the characteristics of a largely semiarid climate and large expanses of steeply sloping limestone outcrop, inhibit conventional estimates of groundwater recharge to the Western Aquifer Basin. Estimates of LTA recharge based on empirical formulae and from soil moisture and 
wetting analysis yield results within the range $270 \times 10^{6}$ to $455 \times 10^{6} \mathrm{~m}^{3} \mathrm{a}^{-1}$. However, the range is too wide to provide a basis for allocation of resources between Israel and Palestine, on either side of the Armistice Line.

The LTA annual recharge to the Western Aquifer Basin aquifer may be as little as $310 \times 10^{6} \mathrm{~m}^{3} \mathrm{a}^{-1}$ (Hughes at al. 2008), or as high as $366 \times 10^{6} \mathrm{~m}^{3} \mathrm{a}^{-1}$ (MNIWC, 1999). A likely and conservative estimate errs on the lower side but the range of values remains too large for equitable allocation of the renewable resource. The significant uncertainty of the location of the eastern recharge boundary, based on structural, topographic or potentiometric divides, also needs resolution. Of these two uncertainties, the LTA recharge is the most challenging to constrain, as the location of the groundwater divide is technically more straightforward although politically sensitive.

Determination of a defensible value for the LTA recharge estimate for the Western Aquifer Basin now depends on gathering the appropriate density of time series data. Until sufficient data have been collected and analysis is satisfactorily concluded, most likely using a combined SMD and WT model, agreement over the allocation of the resource cannot be achieved.

While the LTA annual recharge to the Western Aquifer Basin remains uncertain, there is an increasing risk that the issues of long-term allocation and use of the groundwater resource may be a source of tension. This risk provides considerable impetus to the ongoing evaluation of the resource potential, but the greatest risk is that workers in the West Bank fail to collect time series meteorological, wadi flow and stream flow data of adequate quality and density to constrain future estimates of renewable resources.

Acknowledgement: The work was originally undertaken within the Sustainable Management of the West Bank and Gaza Aquifers Project which was funded by the UK Department for International Development. The project partners included the University of Newcastle and the Overseas Development Institute working alongside the Palestinian Water Authority (PWA), for whom a major outcome was training and capacity building. Data gathering has been and is currently the responsibility of the Palestinian Water Authority. The recharge model was developed by the British Geological Survey. The paper is published by permission of the Director, British Geological Survey (NERC). 


\section{References}

Assaf, K., Khatib. N., Kally, E. \& Shuval, H. 1993. A proposal for the development of a regional water master plan. Israel/Palestine Center for Research and Information, Jerusalem.

Bachmat, Y. 1995. Hydrologic model of the western mountain groundwater basin for Stage 1, Harvard Middle East Water project. Technical report Institute for Social and Economic Policy in the Middle East, Harvard University, USA.

Bredenkamp, D.B., Botha, L.J., van Tonder, G.J. \& van Rensburg, H.J. 1995. Manual on estimation of groundwater recharge and aquifer storativity. Report Water Research Commission, Pretoria TT 73/95.

CDM 1998. Study of the sustainable yield of the Eastern Aquifer Basin final report. Camp Dresser McKee/Morgan report for Palestinian Water Authority and US Agency for International Development, PWA, Ramallah, Palestine.

Deconinck, S. 2006. Water wars: resource issues in Israel and Palestine. In: The Global Environment 2006, Chartered Institution of Water \& Environmental Management, London, pp50-51.

de Vries, J.J Simmers, I. 2002. Groundwater recharge: an overview of processes and challenges. Hydrogeology Journal, 10, 5-17.

Flint, A.L., Flint, L.E., Kwicklis, E.M., Fabryka-Martin, J.T. \& Bodvarsson, G.S. 2002. Estimating recharge at Yucca Mountain, Nevada, USA: comparison of methods. Hydrogeology Journal, 10, 180-204.

Goldschmidt, M.J. 1955. Precipitation and runoff from Jordan and Litani catchments. Hydrological Paper 1, Hydrological Service of Israel, Jerusalem.

Goldschmidt, M.J. \& Jacobs, M. 1958. Precipitation and replenishment of the Yarqon and Nahal Hatteninim underground catchments. Hydrological Paper 3, Hydrological Service of Israel, Jerusalem.

Guttman, Y. \& Zuckerman, C.H. 1995. Flow model in the Eastern Basin of the Mountains of Judea and Samaria from the Pharoah Stream to the Judean Desert. Report TAHAL Consulting Engineers 01/95/66, TAHAL, Tel Aviv, Israel.

Herczeg, A.L., Leaney, F.W.J., Stadter, M.F., Allan, G.L. \& Fifield, L.K. 1997. Chemical and isotopic indicators of point-source recharge to a karstic aquifer, South Australia. Journal of Hydrology, 192, 271-299.

Hoetzl, H. 1995. Groundwater recharge in an arid karst area (Saudi Arabia). IAHS Publication 232, 195-207.

Hughes, A.G., Mansour, M.M., Robins, N.S. \& Peach, D.W. 2006. Numerical modeling of runoff recharge in a catchment in the West Bank. In: Poeter, E., 
Hill, M.C.\& Zheng, C. (eds) MODFLOW and More: Managing Ground-Water Systems - Conference Proceedings, Colorado School of Mines, May 2006, Volume 1, 385-389.

Hughes, A.G., Mansour, M.M. \& Robins, N.S. 2008. Evaluation of distributed recharge in an upland semi-arid karst system: the West Bank Mountain Aquifer, Middle East. Hydrogeology Journal, 16, 845-854.

Lange, J., Greenbaum, N., Husary, S., Ghanem, M., Leibundgut, C. \& Schick, A.P. 2003. Runoff generation from successive simulated rainfalls on a rocky, semi-arid, Mediterranean hillslope. Hydrological Processes, 17, 279-296.

Leduc, C., Bromley, J. \& Schroeter, P. 1997. Water table fluctuation and recharge in semi-arid climate: some results of the HAPEX-Sahel hydrodynamic survey (Niger). Journal of Hydrology, 189, 123-138.

Lerner, D.N., Issar, A.S. \& Simmers, I. 1990. Groundwater recharge: a guide to understanding and estimating natural recharge. International Association of Hydrogeologists, International Contributions to Hydrogeology 8, Verlag Heinz Heise, Hannover.

Lewis, M.F. \& Walker, G.R. 2002. Assessing the potential for significant and episodic recharge in southwestern Australia using rainfall data. Hydrogeology Journal, 10, 229-237.

Mansour, M.M. \& Hughes, A.G. 2004. User's manual for the recharge model ZOODRM. Report British Geological Survey CR/04/151.

McKenzie, A.A., Ó Dochartaigh, B.É \& Saleem, N. 2001. West Bank aquifers groundwater recharge estimation. Report British Geological Survey CR/01/252.

MNIWC 1999. Development of utilization and status of water resources in Israel until Fall 1998. Ministry of Natural Infrastructures Water Commission Hydrological Service, Jerusalem.

Penman, H.L. 1948. Natural evaporation from open water, bare soil and grass. Proceedings of the Royal Society London, Series A, 193:,120-145.

PWA 2004. Hydrogeological Map of the West Bank, 1: 250000 scale. British Geological Survey, Keyworth, for Palestinian Water Authority, Ramallah.

Rofe \& Raffety 1965. West Bank hydrology 1963-1965: Analysis. Rofe \& Rafferty Consulting Engineers Ltd., Amman, report for Central Water Authority, Amman, Hashemite Kingdom of Jordan.

Rogers, J.D. 2004. Water and environment security in the Middle East. In: R.D. Caldwell, J. Ehlen \& R.S. Harmon (eds) Studies in Military Geography and Geology, Kluwer Academic Publishers, 333-343. 
Scanlon, B.R., Tyler, S.W., Wierenga, P.J. 1997. Hydrologic issues in arid, unsaturated systems and implications for contaminant transport. Reviews of Geophysics, 35, 461-490.

Simmers, I., Hendickx, J.M.H., Kruseman, G.P. \& Rushton, K.R. 1997. Recharge of phreatic aquifers in (semi-) arid areas. International Association of Hydrogeologists, International Contributions to Hydrogeology 19, Balkema, Rotterdam.

SUSMAQ 2003. Conceptual Flow Model of the Western Aquifer Basin. In: Wheater, H. and Al-Weshah, R. (eds) Hydrology of wadi systems, IHP-V, Technical Documents in Hydrology 55, UNESCO, Paris.

UNESCO 1983. International legend for hydrogeological maps, revised version. IAH/IASH/UNESCO, Paris.

Wood, W.W., Rainwater, K.A. \& Thompson, D.B. 1997. Quantifying macropore recharge: examples from a semi-arid area. Ground Water, 35, 1097-1106.

World Bank 2009. West Bank and Gaza: assessment of restrictions on Palestinian water sector development. World Bank Middle East and North Africa Region Sustainable Development Sector Note, April 2009 [http://www.irc.nl/url/32408 accessed September 2009]. 
Table 1 Previous recharge estimates $\left(10^{6} \mathrm{~m}^{3} \mathrm{a}^{-1}\right)$

\begin{tabular}{|l|l|l|l|l|l|}
\hline & Mean & Minimum & Source & Maximum & Source \\
\hline $\begin{array}{l}\text { Western Aquifer } \\
\text { Basin }\end{array}$ & 350 & 318 & $\begin{array}{l}\text { Goldschmidt \& } \\
\text { Jacobs (1958) }\end{array}$ & 366 & MNIWC (1999) \\
\hline $\begin{array}{l}\text { Eastern Aquifer } \\
\text { Basin }\end{array}$ & 130 & 119 & $\begin{array}{l}\text { Guttman \& } \\
\text { Zukerman (1995) }\end{array}$ & 197 & CDM (1998) \\
\hline $\begin{array}{l}\text { North-Eastern } \\
\text { Aquifer Basin* }\end{array}$ & 145 & - & $\begin{array}{l}\text { McKenzie } \text { et al. } \\
(2001)\end{array}$ & - & \\
\hline
\end{tabular}

* Too few values to generate maximum and minimum values 
Table 2 Recharge values calculated from the seven model runs for the Western Aquifer Basin (after Hughes et al. 2008)

\begin{tabular}{|l|c|}
\hline & $\begin{array}{c}\text { Western Aquifer Basin } \\
\left(10^{6} \mathrm{~m}^{3} \mathrm{a}^{-1}\right)\end{array}$ \\
\hline WT $20 \mathrm{~mm}$ & 455 \\
\hline WT $30 \mathrm{~mm}$ & 415 \\
\hline $\begin{array}{l}\text { WT } 30 \mathrm{~mm}+\text { urban } \\
\text { +irrigation }\end{array}$ & 430 \\
\hline WT $40 \mathrm{~mm}$ & 387 \\
\hline SMD & 269 \\
\hline SMD+ urban+ irrigation & 297 \\
\hline Composite SMD/WT & $\sim 310$ \\
\hline
\end{tabular}

WT - wetting threshold

SMD - soil moisture deficit 


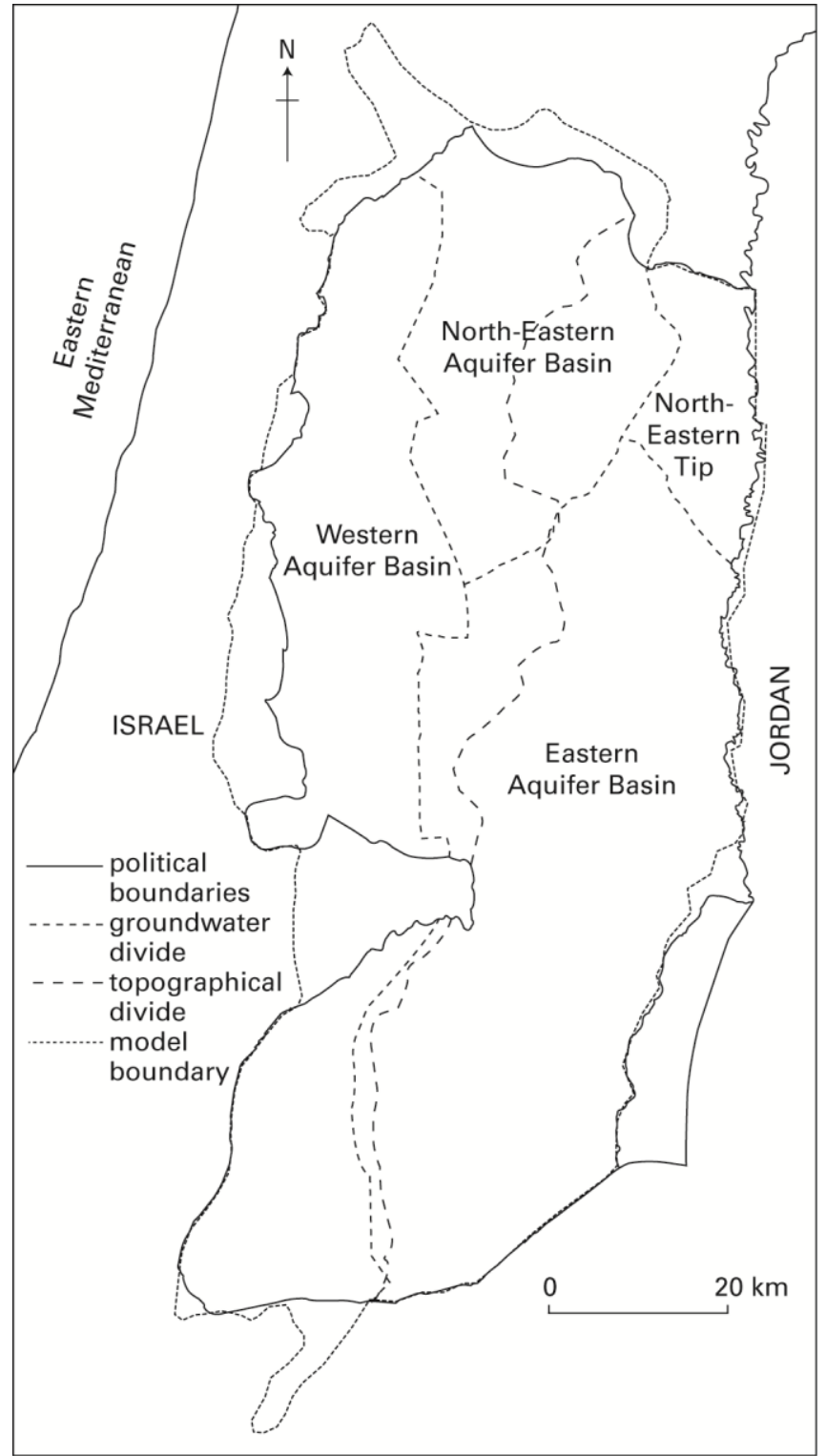

Figure 1 The political boundary of the West Bank with groundwater and topographic divides. 


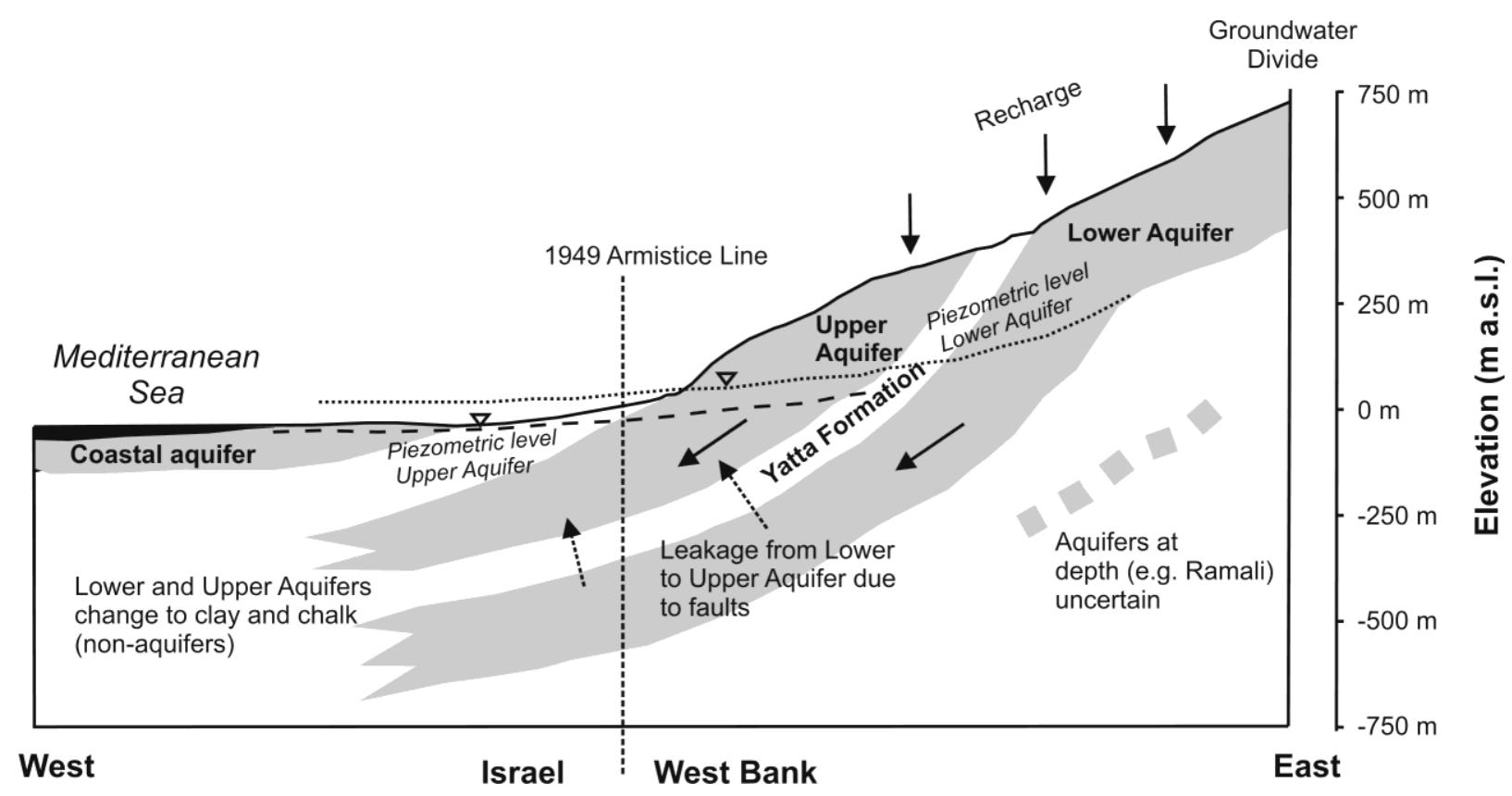

Figure 2 Schematic $70 \mathrm{~km}$ long west-east cross-section of the central part of the Western Aquifer Basin. 